\title{
Social protests and government responsiveness in Nigeria: a study on Bring Back Our Girls Movement
}

\section{Protestos sociais e responsabilidade do governo na Nigéria: um estudo sobre o Movimento "Bring Back Our Girls"}

\author{
Aluko Opeyemi Idowu, \\ Ajayi Crowther University, Nigeria
}

\begin{abstract}
Socio-political movements in any country seek to ensure what they perceive to be equity in governance, accountability of government personnel and prevent issues that could lead to injustice and violence if left unattended. Socio-political movements exist worldwide and, thus, are not peculiar to developing countries. They are excellent tools for expressing democratic nature of a given society and a tool for contestation against undemocratic governments. This paper analyses the actions and reactions of the Bring Back Our Girls (BBOG) socio-political movement in Nigeria. The research question is to what extent has the movement been able to achieve accountability from the government in the quest of restoring the missing Chibok girls? The relative deprivation theoretical framework and political settlement analysis are employed to show the impact of the group reactions on the actions of the government. The analysis domiciles on the government of Nigeria. The paper concludes that democratic growth and development are sustained whenever citizens are able to approach the government by means of social movements and peaceful contestation.
\end{abstract}

Keywords-BBOG, Chibok Girls, Development, Relative Deprivation, Social Movements and Political Settlement Analysis.

Resumo-Os movimentos sociopolíticos em qualquer país procuram garantir o que consideram ser equidade na governança, responsabilização do governo e prevenir questões que poderiam levar à injustiça e violência se não fossem atendidas. Os movimentos sócio-políticos existem em todo o mundo e, portanto, não são peculiares aos países em desenvolvimento. São excelentes ferramentas para expressar a natureza democrática de uma determinada sociedade e uma ferramenta de contestação contra governos não democráticos. Este artigo analisa as ações e reações do movimento sócio-político Bring Back Our Girls (BBOG) na Nigéria. A questão de investigação é perceber até que ponto o movimento foi capaz de obter a responsabilização do governo no retorno das jovens Chibok desaparecidas. A análise do acordo político é utilizado para mostrar o impacto das reações de grupo nas ações do governo. A análise foca-se no governo da Nigéria. $O$ artigo conclui que o crescimento e desenvolvimento democráticos são sustentados sempre que os cidadãos se conseguem aproximar do governo por meio de movimentos sociais e contestação pacífica.

Palavras-Chave-BBOG, Chibok Girls, Desenvolvimento, Privação relativa, Movimentos Sociais e Análise de Assentamentos Políticos.

Submitted-29-04-2020. Accepted-03-12-2020. 


\section{Introduction}

$\mathrm{D}$ EMOCRACY in every region is unique and different in tenets and creeds of operations. The common feature of democracy is the citizens having an impact of some sort, however small in the decision-making process of the country. This political participation is mostly put forward through general election of any kind (government staged managed elections or citizens and or electorates priority election) where the political representatives are validated in office through popular votes (that is, the candidate with the majority of votes is declared elected). Furthermore, and on a negative note, the elections are usually periodical at four or more year intervals; this means that the citizens' major influence on the government to propel accountability is grossly limited to electioneering periods. The governments are, therefore, mostly at liberty to hold the citizen at ransom with bad governance saddled with low accountability as accountability satisfaction from the citizens will be demanded and determined mostly during the general elections.

In recent times, there is a new growing trend or rather a resuscitation of socio-political movements in many developed and developing countries. They are usually groups seeking to drive home some particular social and political issues and agenda so as to ensure equity in the country, accountability of government personnel and prevent issues that could lead to anarchy if left unattended (Fulu and Miedema 2016). These groups, or movements, have paved way for ensuring demands for accountability prior electioneering periods. Some of the global reckon protest landmarks are Occupy Wall Street in the United States over wealth inequality, political corruption, corporate influence of government over unemployment and job discrimination among others, Arab or barbers spring, a series of anti-government protests, uprisings, and armed rebellions that spread across much of the Arab world in the early 2010s. It began in response to oppressive regimes and a low standard of living, starting

- Aluko Opeyemi Idowu, Lecturer in the Political Science Department of the Ajayi Crowther University, Oyo, Nigeria. E-mail: opealukoheavenprogress@gmail.com

DOI:http://dx.doi.org/10.21814/perspectivas.2954 with protests in Tunisia. It was aimed to liberate Arab from autocracy to democracy. The IsraeliPalestine 2018-2019 Gaza border protests, by the Great March of Return over the blockage of the Gaza strips, two state cohabitation agenda and United States recognising Jerusalem as Israeli capital among others. The Occupy Nigeria protest in 2011-13 was aimed at curtailing, bad governance, corruption, insecurity, ethnic chauvinism and religious bigotry among others in the political environment. The Russian protests that was named "For Fair Elections", 2011-13, Chilean student protests 2011-2013 known as the Chilean Winter or the Chilean Education Conflict were a series of student-led protests across Chile, demanding a new framework for education, South Africa Anti-apartheid protest in the early 1990s and the incessant xenophobia protest over the domination of other national against the Locales (Aluko 2019). The 2017 Resume or Resign protest in Nigeria over the Presidents spending more than 90 days abroad seeking treatment for an unspecified illness and Bring Back our Girls protest in Nigeria since 2014 over the kidnap of 214 school girls (PASGR 2020) among many others across the world.

Socio-political movements are not peculiar to developing countries alone but are just as relevant and prominently used (Marcy 2020). It is a relevant tool for expressing democratic rights and the display of political inclusiveness and active participation in the governance of the country (Pathak 2020). Many developed democratic countries, in most cases, see public protest as a medium or last resort provided that all other measures of political engagements such as open or secret dialogues, judicial resolutions, electioneering resorts, among others, usually fail beforehand (Drozdz 2020). The reverse is the case in many developing countries as socio-political action such as protests are seen as the first order of dissent and political engagement with the state because the other means/platforms such as electioneering period, judicial settlement, socio-political conferences (Confab), among others, are slow, mostly staged, and managed by the incumbent government (Aluko 2020a). Therefore, protests are a key tool for socio-political inclusion and for agitation against politics of exclusion and undemocratic governments in most regions. 
tries of the world, the extent of political and social exclusion is high, whereby the majority of the citizens were excluded from governance either during elections by disfranchising them through electoral violence or by militarizing the state to prevent civil unrest or protest thereby making way for aristocratic governance. This, however, makes the atmosphere of leadership and the corresponding offices to become the seat and palace of 'demigods dictatorship (Aremu and Aluko 2017). The extent of political inclusion is restricted to few people usually trusted loyalist further paving way for ethnic chauvinism and religious bigotry in appointing public representatives. This scenario, in most cases, leads to low or none accountability from the leaders or government officials and the country becomes, thus, in jeopardy of gross mismanagement, anarchy, pariah state and or failed state (Aluko 2016; Aluko and Sayuti 2016). There is, therefore, the need for the citizenry to reach out to the government with public protest as socio-political engagement tool at their disposal in order to achieve accountability, equity in the distribution and utilisation of the state largess.

This paper analyses the creed, tenet, actions and reactions of the Bring Back Our Girls (BBOG) socio-political movement in Nigeria. The actions of the government and the resultant reactions to other matter such as governance accountability probe by the citizens through socio political movements. The question this paper seeks to answer is; to what extent has the movement bring back our girls (BBOG) socio political movement in Nigeria been able to achieve accountability on the government in the quest of restoring the Boko Haram kidnapped Chibok School girls? The relative deprivation theoretical framework and political settlement analysis are employed to show the impact of the group reactions on the actions of the government. The analysis domiciles on the government of Nigeria.

\section{Conceptual Clarification}

\subsection{Socio-political movement}

Social movement reflects the notion of social change. A movement is a mixture of organisation and spontaneous reactions. Killian, Smelser and Turner (2017) perceived social movement to be a loosely organised but such that sustain campaign in support of a social goal, such as the implementation or the prevention of a change in societys structure or values. A social movement is also a sustained, organised collective effort that focuses on some aspect of social change. They tend to persist over time more than other forms of collective behaviour.

The individual member experiences a sense of membership in an alliance of people who share his dissatisfaction with the present state of affairs and his vision of a better order. A social movement in other words is a collectivist agenda with a common goal and shared values. The behaviour inherent in social movements reflects the faith that people collectively can bring about or prevent social change if they will dedicate themselves to the pursuit of a goal. Distant sympathisers or observers may regard these goals as unrealistic, but to the members they are hopes that can be easily achieved.

One of the refined characteristics of a social movement is that it has relatively long lasting duration of activism (Drozdz 2020). The activity of the membership is sustained over a period of weeks, months, or even years rather than flaring up for a few hours or a few days and then disappearing. Some social movements' lifespan may lasts for many decades through enlisting of hundreds of thousands of members across various cadres in the society. Some movements take place within the boundaries of a specific secondary group, such as a religious association or a local community, and may include only a few scores or a few hundred members (Turner and Smelser 2017). The actual size of a social movement is not stable or static but dynamic. It changes with the duration. The membership is not formally defined. One of the major characteristics of a social movement is the semiformal character of its structure. It lacks the fully developed, formal structure of a stable association, such as a corporation, or a political party.

There is no legal obligation required to become a member, either to conform to the movements norms or to remain a member, commitment to the movement and its values becomes one of the most essential sources of control. In 1966, cultural anthropologist David F. Aberle identified four kinds 
of social movements: alternative, redemptive, reformative, and revolutionary (Levane 2017). Alternative social movements seek alternative government by trying to mobilise the citizens against the incumbent government. A reformative social movement advocates for minor changes instead of radical changes (Karaliotas and Swyngedouw 2019). For example, revolutionary movements can scale down their demands and agree to share powers with others, becoming a political party. A revolutionary movement is a specific type of social movement dedicated to carrying out revolutionary reforms and gain some control of the state (Abdullah 2020; Marcy 2020). If they do not aim for exclusive control, they are not revolutionary (Karaliotas and Swyngedouw 2019; Abdullah 2020). A redemptive social movement is radical in scope but focused on the individual (Gillan 2019).

Social movements can also be categorised based on specific features such as scope, type of change required, target audience, method of work and range of operation. Scope: A movement scope can be either reform or radical. The type of change indicates either innovative or conservative. An innovative movement wants to introduce or change norms and values while a conservative movement seeks to preserve existing norms and values. The targets audience might be a group- or society focused movement. An attempt to change the political system from a monarchy to a democracy, for example, is group focus. An individual-focused movement seeks to affect individuals. The method of work: peaceful movements utilise techniques such as nonviolent resistance and civil disobedience or, instead violence, in such a case of a violent movement seeking social change. The range of operation category might be global movements, or local movements seeking to preserve an historical building or a natural habitat.

While technology, population, environmental factors, and racial inequality can prompt social change, true social change can be attained only when members of a society organise into social movements. Wherever they occur, social movements can dramatically shape the direction of society. Even when they prove initially unsuccessful, social movements do affect public opinion. In Political Sociology, the theory relative deprivation has been used to explain why people mobilise for change, and political settlement analysis has been proven to be a veritable tool of social movement group.

\section{Theoretical framework}

\subsection{Relative Deprivation Theory and Political Settlement Analysis}

Two theories are used to buttress the reason for socio political mass mobilization also to explain social protests and government responsiveness. The relative deprivation theory is structured to explain the reason why people organize social protest. This reason is due to perceived relative deprivation of their basic rights such as right to life, food, freedom of association among others, On the other hand, the political settlement analysis explains how such protests or agitations can be settled in a peaceful and amicable way among all the parties involved.

The Relative Deprivation Theory is adopted in this study as propounded by Dollard, Miller, Doob, Mowrer, and Sears (1939) as part of efforts to link socio-political and economic inequalities in a given society to the emergence of rebellions and insurrections while providing the basis for understanding the complexity of socio-economic and security challenges. Naturally, people feel aggrieved if they are deprived or denied fundamental rights like, right to food, health, security, political participation, wealth and dignity among others. Consequently, one could resort to any means, including the use of violence to achieve his or her goals and aspirations.

Relative Deprivation occurs where individuals or groups subjectively perceive themselves as unfairly disadvantaged over others who have similar attributes and deserving similar rewards (their reference groups) (Aluko 2017a; 2017b). Indeed, relative deprivation is more likely when the differences between the two (conflicting) groups narrow so that comparisons can be easily made than where there are caste-like differences. The discontent arising from relative deprivation has been used to explain radical politics, the rise of social movements, industrial disputes and the whole plethora of crime and deviance (Aluko 2020b).

The feelings of relative deprivation arise when desires become legitimate expectations, and those 
desires are blocked by society. Social satisfaction is the opposite of relative deprivation. Relative deprivation is generally considered to be the central variable in the explanation of social movements and is used to explain the quest for social change that inspires social movements; social movements emerge from collective feelings of relative deprivation (Morrison 1971).

The usual distinction made is that religious demands for political change are a collective response to relative deprivation. For example, smuggling, kidnapping, poaching or terrorism - have a collective nature and a communal base and does not even allow for gang delinquency which is clearly a collective response. Relative deprivation theory distinguishes between egoistic deprivation and fraternal deprivation. Egoistic deprivation refers to a single individual's feeling of comparative deprivation. Fraternal deprivation, also called group deprivation, refers to the discontent arising from the status of the entire group as compared to a referent group. This is similar to the BBOG agitations for the release of the Boko Haram kidnapped Chibok girls. Fraternal deprivation may strengthen a group's collective identity (Singer 1992).

In Nigeria relative deprivation is more prominent in socio-economic inequality (Aluko 2020a; 2021). The nature of the government response to the citizens security challenges and basic amenities calls for an uprising. This is because the system gives credence to segregation among groups (ethnic, religion and political alliances) that give few individuals the economics of surplus values and self interests, personal aggrandisement and that promote monopoly for commodities which different interest groups in the society are entitled to (Aluko 2021). Security challenges in Nigeria are therefore seen as an extension of social conflicts which antagonise relations between various groups in the society. Relative Deprivation Theory argues that when expectation outstrips current achievement regardless of the absolute levels of economic consumption or the provision of political rights, frustration is regenerated (Aluko 2017b; Aremu and Aluko 2017). Therefore, the collective frustration turns to anger or violence against the object that instigates the frustration, usually the government.
By application, this theory assists us to trace the historical antecedence of Bring Back Our Girls agitations and frequent rise of individuals and groups against the Nigerian government. From the standpoint of the assumption of Relative Deprivation Theory, we argue that the abysmal failure of the Nigerian government to addressing critical challenges to development in many parts of the country may be responsible for the internal insurrection by armed militia groups against the state. Furthermore, the security challenges or threats in some parts of Nigeria particularly the Boko Haram inflicted northern region, are clear indications that government seems to have stumbled and fallen in her constitutional role of protecting lives and properties of the Nigeria people. This led to the kidnapping of about two hundred and fifty (250) Chibok school girls and the resultant persistent agitation for swift action from the government by the BBOG social-political movement.

The increasing rate of poverty among Nigerians, unemployment, per capita income is low and high rate of inflation has not been effectively addressed $^{1}$. Similarly, Nigerians are still facing challenges of low health status, poor state of infrastructures, high rate of illiteracy, low technological development, Niger delta insurgency, the revamping of Biafra secessionist agenda in the eastern Nigeria among other (Aluko 2017a; 2017b; 2017c). It is therefore expedient for a rapid response of good governance which will culminate into growth and development to take place within a short time so that the impending danger of chaos or rancour ravaged state will be avoided. The government of Nigeria, therefore, need to engage some of the prominent actors of the social movement's groups in a political settlement strategy.

\subsection{Political Settlement Analysis}

A political settlement analysis is a measure of engaging violent prone or any other agitating faction in the state in a peaceful and purposeful settlement. While the term "political settlement" has recently gained prominence amongst academics,

1. GNI pc $(2019)=2.030 \$$ USD; (access on 11 november, 2020: https://data.worldbank.org/country/NG). Unemployment rate $2020=7,98 \%$ (access on 11 november 2020: https://www.statista.com/statistics/382366/unemploymentrate-in-nigeria/) and inflation rate on 2020 . 
practitioners and policymakers, there is still a considerable lack of clarity of what a political settlement actually is. Some see a political settlement as an outcome of political negotiation, a high-level agreement that paves the way for some new legal structure (include examples of authors who abide for that definition). Others feel that political settlements are not static but continually evolving processes, through which the allocation of power in a given society is continually revised, as different configurations of stakeholders vied for visibility or influence in the political marketplace.

A political settlement is a legitimate process of negotiation between groups or power holders leading to power-sharing, forgiveness, reconciliation, security and peace. The term "political settlement" is increasingly popular in political economy analyses. Despite this popularity and consensus, Mushtaq (2009) offers his own specific definition. He presents a political settlement as "a combination of power and institutions that is mutually compatible and also sustainable in terms of economic and political viability" (Mushtaq 2009). He specifies that institutions and the distribution of power have to be compatible because if powerful groups are not getting a fair distribution of benefits from an institutional structure, they will strive to change it. The combination also has to be sustainable because institutions, both formal and informal, have to achieve the minimum levels of economic performance and political stability that are required for the reproduction of societies.

\subsection{How political settlements are maintained}

There are several different ways through which political establishment establish, consolidate, or strengthens a political settlement. The most basic is coercion. The ultimate form of coercion is to amass the capacity to use, or threaten to use, physical force. This generally means securing control of the police and military forces. In an extremely fragile situation of state collapse, an elite coalition prevails by assembling enough military power to defeat competing coalitions (Parks and Cole 2010). More generally, coercion includes actions by the ruling coalition to impose their interests on other groups, including excluded elites that might challenge it. This is similar to a govern- ment fighting internal insurrections and terrorism extremists such as Boko Haram in Nigeria.

The second method for sustaining a political settlement is through co-optation of potential threats from powerful excluded elites. This is often done by allowing these elite groups, social movements to play a role in the political settlement, which then may be formalised.

The third method to consolidate the position of a ruling coalition, and ultimately the most important for the long-term viability of a political settlement, is through building and maintaining the legitimacy of state institutions established and shaped through the political settlement. Whaites (2008) notes that "even the most repressive states seek to stake a claim to some form of legitimacy, essentially a claim that state institutions have a moral right to continue to lead the state building process." The more widely the claim to legitimacy is accepted, the greater the prospects for stability of the political settlement.

The fourth method through which political settlements are maintained is through the actions of the international community. International actors may exert a stabilising influence through a wide range of mechanisms (Parks and Cole 2010). One obvious method is through the presence of external security forces and exerts pressure on another state to grant the desire of the people. They are able to extend or reinforce the capacity of the agitating groups or social movement and the ruling coalition to keep potential competitors in check. This might be through massive foreign assistance transfers that may also strengthen a political settlement, especially insofar as the social movement groups and the ruling coalition is able to capture most of the benefits.

\section{Socio-Political Action and Move- ments in Nigeria}

Nigeria is a vast country with many interest groups, ethno-religious groups and social diversities. Since the inception of independence in 1960, several socio-political movements that have fought the government for their fundamental rights had emerged (Aluko 2017a). A reasonable sum of such socio-political groups has failed to drive home their agitations and secure their needs 
from the government. Many other social movements have short-lived, and their agenda were thwarted due to incoherent alignment and poor articulation of their agenda with the government. A few prominent socio-political actions and movements will be analysed in this section.

The various Niger delta and South East movements became more volatile primarily due to political marginalisation and underdevelopment occasioned by blatant environmental pollution and despoliation of natural ecosystem due to oil exploration activities by the federal government and Multinational Oil Corporations (MNOCs). An attempt to compel the state and MNOCs to remedy the injustices meted to the region since the discovery of crude oil in commercial quantities at Oloibiri, in 1956, led to sociopolitical movements and agitations, insurgency and counter-insurgency violence. Environmental Movement Organisations (EMOs) and armed nonstate youth organisations emerged in a bid to counteract the continued harassment, intimidation, oppression and repression of the Niger Deltans by the Nigerian state and its collaborative partners-the MNOCs.

In other to further internationalise and alleviate the plight of the delta minorities to an equity position in both internal and international discourse the socio-political movements as EMOs emanate as peaceful association and some others later turn out to become violent due to reprisal attacks from the Nigerian state. EMOs such as MOSOP, Urhobo Youth Movement (UYOMO), Ikwerre Youth Movement (IYM), and Ijaw Youth Council (IYC) (Omotola 2009). Besides, non-state armed groups erupted violently such as the Federated Niger Delta Izon Communities (FNDIC), the Membutu Boys, the Niger Delta Vigilante (NDV), the Niger Delta Peoples Volunteer Force (NDPVF), the Coalition for Militant Action (COMA), the Movement for the Emancipation of the Niger Delta (MEND), and the Martyrs Brigade among other fractionated groups (Aluko 2016).

Subsidy removal coalition protest in 2012 was a nationwide social action which was short-lived but achieved some measure of positive impacts on the polity. The protest was due to the increase in the pump price of Premium Motor Spirit (PMS) from N65 to N141 (more than 100\% increment) following the removal of oil subsidy. Following years of neglect of the nations refineries, government imports refined petroleum products like kerosene, petrol and diesel. In order to keep the prices affordable, the government says it pays a subsidy, being the difference between the cost of importation and the locally regulated prices. The organised labour (spearheaded by the Nigerian Labour Congress and Trade Union Congress), and a coalition of civil society groups, opposition politicians, and professional associations all of which banded together into a Joint Action Front prosecuted a five-day nationwide protest intended to get the government to reverse the fuel subsidy removal and revert to the N65 pump price of PMS (Agbedo 2012). The protests led to the emergence of occupy Nigeria social movement (\#OccupyNigeria).

Recently the Bring Back Our Girls sociopolitical movements erupted out due to the untamed terrorist and kidnapping actions of the Boko Haram syndicates. In April 2014, 276 Chibok Christian Community school girls of age range 15-18 years among many others kidnapped by the Boko Haram terrorist group and forced into marriage and servitude to its members. Though this was the largest single abduction carried out by this group. However, according to Amnesty International, Boko Haram has abducted approximately 2,000 girls and women. This number is likely even higher as there are no accurate figures for their activities.

\section{Bring Back Our Girls and Account- ability Expedition}

The right to life, association, religion and education, are part of the cardinals of the fundamental human rights. Whenever any of such rights are bridged, the citizens have the right to seek for redress through all means possible and available. Part of these means include the use of protest and organised social movement such as the Bring Back Our Girls. The Bring Back Our Girls sociopolitical movement is very important because of some basic reasons. Firstly, it is an act of injustice to keep quite in a civilised society when there are bridges on the right to life and education (especially the girl child in sub Saharan Africa 
where the level of education given to girl child is low). The act of kidnapping of the school girls by Boko Haram and the silence of the government is a case of injustice and evil that propelled the BBOG socio-political movement to be "brother's keeper" because the injustice done to one citizen is the injustice that might be replicated on the rest of the citizenry as well. Secondly, the campaign is focused more on the Nigerian government than on Boko Haram (Zenn 2014). The government has not been proactive and responsive as at when due therefore there is a need for both internal and external pressure to be mounted on the government so as to make it break it shell of nonchalance to the issues that concern the esteemed citizenry.

Thirdly, the outcry of the pioneer organisers of the Bring Back Our Girls socio-political movement has gotten other governments involved. These foreign governments are therefore offering social, cultural, political, economic and psychological resources and support to ensure that the kidnapped girls are brought back before it is too long. These also influence the host government to step up both military and intelligent resources in the quest to restore the girls and possibly quench the Boko Haram terrorist movement.

Fourthly, the action campaign as well is to sensitise the local communities in Nigeria of the grave damages done already to the immediate environments, lives and properties and the impending disasters on the future of Nigerian youths if the wave of kidnapping and terrorisms are not curbed as fast as possible. It has the dimension of socioeconomic downturn impact on the economy if the tide of the insurgent and violent wave in the country is not quenched. Also, the masses are at the receiving end because they are the most vulnerable to the impact of the scourge of the terrorist attack not the government personnel and their kit or kindreds who might not be within the shores of the country.

Fifthly, the kidnapping is not just an act of terror. From liberal feminism point of view, it is an attack on women everywhere in the world. The terrorists targeted a girls school in a region predominated by Christians because their warped brand of Islam does not allow girls to be educated. This action if proper and rapid political care is not taken, the entire Christian communities in Nigeria and elsewhere in the world could engage in a religious war due to the sacrilege committed to their Christian fellow believers. Also women all over the world could pinch on the claim that the legitimate rights of the girl child rightfully packaged in the affirmative action had been violated and rapid response is needed against the government so as to tame the monsters of terrorism internal insurrections.

Lastly, Bring Back Our Girls is thus far a non-violent response to a violent action thereby seeking accountability from the government. Its membership cut across people of many religions because the girls are majorly Christian and a few Muslims, therefore violence option cannot be the first option (Bring Back Our Girls campaign 2015). The kidnapping of the girls have affected so many around the world because the attack was on a gender base mass scale operations. It is also purported that the girls will be facing such a cruel and gruesome future. Therefore, accountability and show of statesmanship is needed from the government so as to be able to sustain it popular mandate given to it by the esteemed electorates and the general citizens of the country.

\subsection{Government response}

Most of the representatives of the Nigerian government involve the use of highly emotional evaluative words, many of them depicting disdain, anger and hatred. Some of the negative evaluations were reacting to the general perception that the Nigerian government was not doing enough to rescue the girls; some campaigners attributed their ineffectiveness to indolence and incompetence (Chiluwa and Ifukor 2015). Some social critics had criticised them for being non-proactive to the Boko Harams threats. According to the Daily Telegraph (26 May 2014), the Nigerian military through its Chief of Defence Staff, Air Marshal Felix Badeh claimed that they had discovered where the 200 kidnapped girls were being held but would not apply force to rescue them. Moreover, the Nigerian government on 29 May 2014 banned all "bring back our girls" demonstrations at Abuja, claiming that the protests posed a security threat to citizens (see Time.com, 2 June 2014). They also called off the deal with Boko Haram to release 
the girls in exchange for the release of imprisoned Boko Haram members (see The Week, 7 July 2014).

The government of Nigeria in recent times had step up the security network to curtail the menace of the Boko Haram group by using more of politico-military tactics unlike the religiouspolitical agenda which it adopted and almost the entire North-eastern Nigeria was turned upsided-down by the terrorist Islamic agenda aggrandisement. The military weaponry and arsenal were fortified to face the internationally supported Boko Haram arsenal. This had inflected some destabilisation among the group and the entire sect shattered to fractions which is much more penetrable. This had made the negotiation for the release of the girls to be rapid and much possible. Of resent, the military announce the capturing of about one hundred of the Chibok school girls from the terrorists. They also promised to reclaim some of the strong holds of the Sambisa forest fortress of the terrorist group. It is imperative to note that the sit out group of the BBOG socio-political movement has promised not to stop pressurising the government until the entire girls had been released without any remainder.

\subsection{International patronage}

The international patronages the BBOG sociopolitical movement has enjoyed have paved ways for the quest for accountability of lives and properties from the government of Nigeria. The South African Association of Women Graduates (SAAWG) joins other international body, IFUW, as well as all the other organisations and agencies to call on the federal government of Nigeria for the immediate release and safe return of the over 200 school girls. They further demand that the Nigerian government should take urgent steps to ensure that the girls are returned to their families unharmed and can continue their education in a safe environment.

This clarion call and support for the BBOG is sacrosanct because safe access to secondary education is indispensable to the development of communities and countries. Girls should not be faced with such brutal acts of violence and under no circumstances treated as objects for political or sectarian purposes. It is noteworthy to emphasise that the abduction of children is a crime and illegal under international law. Nigeria ratified the Convention on the Elimination of All forms of Discrimination Against Women (CEDAW) without reservations in 1985 and is bound to incorporate its provisions in domestic legislation. It is therefore imperative on the Nigerian government to fulfil all obligations under international and national law. It will also be essential that adequate counselling is provided to the girls, their families and, indeed, their communities.

Kidnapping and abductions are criminal acts and there is an urgent need to be recognised as being exactly that. School girls cannot be used as weapons of war nor denied their human rights of freedom, of access to education and the right to reach their full potential. Bowen (2015) noted that in South Africa, there exists within various districts in rural KwaZulu-Natal the abductions of schoolgirls. It is cultural termed as "Ukuthwala". The cultural term used for this practice still implies a criminal act that the authorities and local police must take swift actions before it degenerates to uncontrollable mass actions of kidnapping. Such actions fall under the term harmful cultural practices in South Africa and a number of local organisations are working to ensure this aspect of gender-based violence is included in the United Nations Post-2015 Declaration (Bowen 2015).

\subsection{Mass Media awareness}

The mass media has also helped the group to claim some accountability from the government by exposing the extravagant life style of the government personalities at the expense of the wellbeing of the teeming populace. The military extravagant and diversion of the money meant to buy weapons, pay embattling soldiers in the warring region are exposed. Indeed, the mass media had kept the hope of the BBOG group alive and visible to all other sympathisers locally and internationally. Prominent personalities from the cream de la cream of the expanded globe had pull their weight behind the group to ensure the government of Nigeria complies with the fundamental human rights of the kidnapped girls and other who are similarly afflicted. 
Several agencies joined in the online BBOG movement in their campaign and quest to achieve their aim of bringing the government to account as torching the lives of the citizenry. Such news media include international media outlets as CNN in the United States of America, BBC in Britain, CTV in China and a host of others. Individuals such as Malala Yousafzaia, a Pakistani girl aged seventeen, visited Nigeria on this first anniversary of the Chibok girls captivity among other prominent political figures that carries the hash tag BBOG during the one year sit-out campaign (Ellis 2016; Maxfield 2016). About two thousand five hundred (2500) corpus of tweets and another two thousand five hundred (2500) Facebook posts comprising about twenty five thousand $(24,983)$ words in total were gathered in 2015 (Chiluwaand Ifukor 2015) from the global campaign. These show a massive followership pulled by the hash tag BBOG. This makes the government to be much more responsive in terms of brutality against the BBOG socio-political movement due to the global attention which the movement had brought on the political and security state of the government and a rethinking of peace by fulfilling the demands of the movement.

\section{Impact of Bring Back Our Girls and Accountability Expedition}

The BBOGs socio-political movement has caused some social psychology accountability impact in the politicking space of Nigeria. Several people in the past had been kidnapped, killed and mutilated without any government attention drawn to it. In the cases where attentions were drawn, the executives as in terms of the security agents do down play the gravity of the incidence thereby handling the matter with levity. The incidence of the Chibok girls in Bornu State Nigeria was initially regarded as a flimsy gainsaying from the press and much naysayers took to the street by saying it is a mere rumour (Maiangwa and Amao 2015). The BBOG efforts and intensity brings a social psychology dimension to the agitations on the government that the girls are also human beings who need to be catered for. The government thus so far reasoned along with the BBOG global campaigns and intensified their efforts in restoring the girls back to the freed society.

The BBOGs socio-political movement efforts had bring about some measures of political accountability and impact advantages in the polity. It is a general norm that the government which include the executives, legislatures and some aspects of the judiciary were elected directly or indirectly through the popular mandate of the citizens of Nigeria (Aremu and Aluko 2016). Therefore, there is the need for the government to listen to the yearnings of the people and grant their request as at when due and as prompt as possible. Prior to the advent of the viral voluntary campaign of bring back our girls, the only possible time to bring the government to account is during the general or supplementary elections after a period of four years (Brents 2016; Aremu and Aluko 2016). But the government was seen to buckle up to the terms of the conveners of the BBOGs movement by activating the political settlement machinery of negotiating with the terrorists group and at the same time sensitising the polity that the situation will be solved in a record time.

The military sector of the country is also put to test and accountability podium. The Nigerian Army is noted for rapid response to security matters across the world. They have successfully at different times in conjunction with the United Nations and or African Union combined military forces to quench the fiery violent attacks against some states in Africa. The internal insurrection and external aggressions of the Boko Haram terrorist group had slightly pushed back their expansionist capabilities and tendencies. However, the BBOGs group has been able to pressurise the government and the government has in turn been able to coordinate the military and demand for accountability over the whole military budgets, weaponry and arsenal build up against internal insurrections. The military sector was able to recover all the land territories overtaken by the militants and pushed the terrorist group up north. In return, some of the kidnapped girls were freed by barrel of guns and military negotiations.

The BBOGs socio-political movement has been able to as well drive a moral accountability impact on the whole country-Nigeria and other parts of the world. The nation was sensitised 
about the realities of the atrocities committed by the Boko Haram and moral sympathy were aroused for the concerned Northeast region and most especially for the over two hundred kidnapped Chibok school girls who were at the verge of writing their school examinations. A moral belonging faculty were set up by the BBOG across the world by their persistent agitations that the girls are their children, daughters, sisters, and girls, they should not be left mutilated and unattended to by the government and other well meaning people of the world. This moral and emotional weapon has made the most significant impacts in the struggle so far and also it is the most potent democratic weapon that has sustained the group for about three years of their existence.

\section{Conclusion}

Democratic growth, development and accountability will be sustained whenever the citizens of a country are able to engage the government on platforms as socio political movements and peaceful agitating groups other than electioneering periods. The more the citizens uses alternative measures to engage the government unlike the conventional electioneering period, the more democratic dividends they will derive and at the same time the stronger the political participation, political culture and socio-political accountability in such polity will be. Once the political participation, political culture and socio-political accountability in a democratic state get stronger, there is more tendencies to have strong state building and reduce corruption because the people can easily protest peacefully and seek for more democratic accountabilities.

The Bring Back Our Girls socio-political movement has been able to erupt out a new form of peaceful socio-political action in the country unlike the conventional militancy in the Niger delta, war of words among the Yoruba Afeneifere groups, the Ndigbo in the Igbo community and the Arewa forum among the Hausa/Fulani ethno cultural groups. The religious groups also do create some unfathomable tension and polarity in the country but the BBOGs socio-political movement has been able to surpass the manifestations of gender, ethno religious and political affiliation tendencies and disparities to front a united banner for new socio-political action in Nigeria and a template for other countries across the globe.

Although the total number of the kidnapped Chibok school girls has not been totally recovered, however, a substantial and logical outcome had been achieved by the BBOG socio-political movement. This paper revealed that the BBOGs is one of the recent and viable, non gender based, non ethnic based, religiousness-less socio-political action groups in Nigeria that uses political settlement analysis and capitalises on the relative deprivation perverse in the country to achieve it aims by regular dialogue and refusal to compromise on their popular demands on the government. The accountability expedition of the BBOGs gained prominence via the social and mass media campaigns, international patronages and frequent or everyday sit out peaceful agitations. The impacts are felt in the areas of socio psychological accountability from the government; political accountability is obtained before the conventional electioneering period. Moral accountability is also obtained from the entire citizenry of Nigeria, independent international organisations, prominent international business, social and political figures across works of life and the sympathy of the entire world is gained over Boko Haram kidnapped Chibok School girls human right violation saga.

\section{References}

[1] Abdullah, Farhad Hassan. 2020. Revolution in Egypt: Political Movements and Mobilisation of Resources. Insight on Africa 12(1), 7-28.

[2] Agbedo, Chris. 2012. "Placards as a language of civil protest in Nigeria: A systemic- functional analysis of the fuel subsidy crisis." Paper presented at the 1st International Conference Chinua.

[3] Achebe Lecture Series. 2012. Aggression Faculty of Arts, University of Nigeria Nsukka-Nigeria, 2327 April. New Haven: Yale University Press.

[4] Aremu, Fatai, and Aluko Opeyemi 2017. Tension in the Paradise: A Paradigm Shift in Urban Violence in Nigeria Silpakorn. University Journal of Social Sciences, Humanities, and Arts 17(1), 262-265.

[5] Aremu, Fatai, and Aluko Opeyemi. 2016. Nigerias 2015 Elections: Permanent Voters Cards, Smart Card Readers and Security Challenges. Journal of Africa Elections South Africa 15(2), 50-68.

[6] Bowen, Hazel 2015. "Bring Back Our Girls - wherever they are being abducted." Speech National President South African Association of Women Graduates (SAAWG) South Africa. 
[7] Brents Helen. 2016. Hashtag in girl hood:\#IAmMalala, \#BringBackOurGirls and Gendering Representations of Global Politics. International Feminist Journal of Politics $18(4)$.

[8] Bring Back Our Girls Campaign. 2015. Official website at www.bbogfamily.ng (last accessed november 11, 2020)

[9] Chiluwa, Inocent, and Ifukor Prisley. 2015. War against our Children:Stance and evaluation in \#BringBackOurGirls campaign discourse on Twitter and Facebook. Discourse Society, 130.

[10] Dollard, John, Neal E. Miller, Leonard W. Doob, O. Mowrer, and Robert R. Sears. 1939. Frustration and aggression. New Haven, CT: Yale University Press.

[11] Drozdz, Martine. 2020. "Maps and protest." In International Encyclopedia of Human Geography, 367-378.

[12] Drozdz, Martine. 2020. "Maps and protest." In International Encyclopedia of Human Geography, 367-378.

[13] Ellis, Miriam. 2016. Cyberactivism: An assessment of the Power of Social Media Campaigns and it relationship to traditional media coverage. |urlwww.commons.cuportland.edu.

[14] Fulu, Emma, and Miedema Stephanie. 2016. Globalisation and Changing Family Relations: Family Violence and Women Resistance in Asian Muslim Society. Sex Role 74, 11-12.

[15] Gillan, Kevin. 2019. "Social movements, protest, and practices of social change." In The Wiley Blackwell Companion to Sociology, 301-318.

[16] Karaliotas, Lazaros, and Erik Swyngedouw. 2019. "Exploring insurgent urban mobilizations: from urban social movements to urban political movements?." In Handbook of Urban Geography. Edward Elgar Publishing.

[17] Levane, Peter. 2017. What is a social movement? http:// peterlevine.ws $/ \mathrm{p}=1826911 / 8 / 2017$.

[18] Lewis M. Killian, Neil J. Smelser, and Ralph H. Turner. 2017. Social movement. https://www.britannica.com/ topic/social-movement (last accessed november 11, 2020)

[19] Maiangwa, Benjamin, and Amao Olumuyiwa. 2015. Daughters, Brides, and Supporters of the Jihad: Revisiting the Gender-Based Atrocities of Boko Haram in Nigeria. African Renaissance 12(2).

[20] Marcy, Richard T. 2020. Leadership of socio-political vanguards: A review and future directions. The Leadership Quarterly 31(1), 101372.

[21] Maxfield, Mary. 2016. History Retweeting itself: Imperia Feminist appropriation of "Bring Back Our Girls." Feminist Media Studies 16(5).

[22] Mushtaq, Khan. 2009. Political Settlements and the Governance of Growth-Enhancing Institutions. https://eprints.soas.ac.uk/9968/1/ Political_Settlements_internet.pdfassessedon3/10/2020.

[23] Omotola, Sola. 2009. Dissent and State Excesses in the Niger Delta, Nigeria. Studies in Conflict and Terrorism $32(2)$.

[24] Opeyemi, Aluko. 2021. "Cycle of Poverty in Developing Countries." In Handbook of Research on Institution Development for Sustainable and Inclusive Economic Growth in Africa, edited by Osabuohien, Evans S., et al. IGI Global.

[25] Opeyemi, Aluko. 2020a. Backdoor Politics: Permitting Informalities for Formal Development in African Democracy. TEME Journal for Social Sciences XLIV(1), 209-229.

[26] Opeyemi, Aluko. 2020b. Breaking the Cycle of Corruption in Nigeria: The Myth and Reality. Journal of Co-operative and Business Studies (JCBS) 5(1), 115-125.

[27] Opeyemi, Aluko. 2019. Re-Visiting Nigerias African Centre Piece Foreign Policy Debt Amidst South African Xeno- phobic Attacks. Nigerian Forum: Journal of The Nigerian Institute of International Affairs (NIIA) 40(11), 498-508.

[28] Opeyemi, Aluko. 2017a. Urban Violence Dimension in Nigeria: Farmer and Herders Onslaught. AGATHOS 8(1).

[29] Opeyemi, Aluko. 2017b. Political Economy of Crony Inequality Among Nations: A Study on Capitalism and Socialism. Journal of Community Development Research (Humanities and Social Sciences) 10(2).

[30] Opeyemi, Aluko. 2016. Policing Election and Electoral Violence in Developing Democracies. Indian Philosophical Quarterly 37(1-4).

[31] Opeyemi, Aluko, and Usman Sayuti. 2016. Visiting The Hippopotamus: National Integration Issues in Nigeria. Romania Journal of Regional Science 10(1), 67-83.

[32] Opeyemi, Aluko. 2016. Refocusing The Focus, Metafocus And Profocus: Mopping Urban Violence in Developing Cities. Journal of Social Science 5(2).

[33] Parks, Thomas, and Cole William. 2010. Political Settlements: Implications for International Development Policy and Practice. Occasional Paper 2.

[34] Partnership for African Social and Governance Research (PASGR). 2020. Bring Back Our Girls - Nigeria New Forms of Social and Political Action: A Study of \#BringbackOurGirls, Nigeria https://www.pasgr.org/what-we-do/ research/research-projects/bring-back-our-girls-nigeria/.

[35] Pathak, Kamal. 2020. "Understanding Peasant Movements with Some Socio-Political including Assam Propera Study on Theoretical Framework." Journal of Social Science for Policy Implications 8(1), 5-8.

[36] The Asia Foundation Supreme Court of Nigeria. 2017. Rules of the Supreme Court of Nigeria http:// supremecourt.gov.ng/ActsRules/Rules_Supreme_Court

[37] Turner, Ralph, and Smelser Neil 2020. Social movement. https://www.britannica.com/topic/social-movement. (last accessed on october 3, 2020.)

[38] Whaites, Alan. 2008. States in Development: Understanding State-Building. Governance and Social Development Group, Policy and Research Division, DFID Working Paper.

[39] Zenn, Jacob. 2014. Boko Haram: Recruitment, Financing, and Arms Trafficking in the Lake Chad Region. Counterterrorism Centre Sentinel (CTC), 7(10).

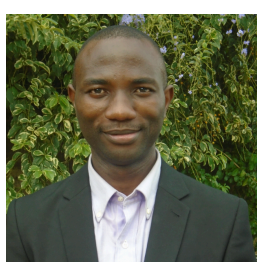

Aluko Opeyemi Idowu $(\mathrm{PhD})$ is a lecturer of the Political Science Department at the Ajayi Crowther University, in Oyo, Nigeria. His scholarship is on Comparative Politics with special focus on Urban Violence studies and Electoral Studies among others. He has more than eighty $(80)$ publications in both International and National credible outlets. 